University of Nebraska - Lincoln

DigitalCommons@University of Nebraska - Lincoln

\title{
Uncertainty in modelling of faecal coliform overland transport associated with manure application in Maryland
}

A. K. Guber

USDA-ARS, Andrey.Guber@ars.usda.gov

Y. A. Pachepsky

USDA-ARS

A. M. Yakirevich

Ben-Gurion University of the Negev

D. R. Shelton

USDA-ARS

A. M. Sadeghi

USDA-ARS

See next page for additional authors

Follow this and additional works at: https://digitalcommons.unl.edu/usdaarsfacpub

Part of the Agricultural Science Commons

Guber, A. K.; Pachepsky, Y. A.; Yakirevich, A. M.; Shelton, D. R.; Sadeghi, A. M.; Goodrich, D. C.; and Unkrich, C. L., "Uncertainty in modelling of faecal coliform overland transport associated with manure application in Maryland" (2011). Publications from USDA-ARS / UNL Faculty. 560.

https://digitalcommons.unl.edu/usdaarsfacpub/560

This Article is brought to you for free and open access by the U.S. Department of Agriculture: Agricultural Research Service, Lincoln, Nebraska at DigitalCommons@University of Nebraska - Lincoln. It has been accepted for inclusion in Publications from USDA-ARS / UNL Faculty by an authorized administrator of DigitalCommons@University of Nebraska - Lincoln. 


\section{Authors}

A. K. Guber, Y. A. Pachepsky, A. M. Yakirevich, D. R. Shelton, A. M. Sadeghi, D. C. Goodrich, and C. L. Unkrich 


\title{
Uncertainty in modelling of faecal coliform overland transport associated with manure application in Maryland
}

\author{
A. K. Guber, ${ }^{1 *}$ Y. A. Pachepsky, ${ }^{1}$ A. M. Yakirevich, ${ }^{2}$ D. R. Shelton, ${ }^{1}$ A. M. Sadeghi, ${ }^{3}$ \\ D. C. Goodrich ${ }^{4}$ and C. L. Unkrich ${ }^{4}$ \\ ${ }^{1}$ USDA-ARS, Environmental Microbial and Food Safety Laboratory, Bldg.173, Powder Mill Rd, BARC-EAST, Beltsville, MD 20705, USA \\ ${ }^{2}$ Department of Environmental Hydrology \& Microbiology, Zuckerberg Institute for Water Research, Jakob Blaustein Institutes for Desert Research, \\ Ben-Gurion University of the Negev, Israel \\ ${ }^{3}$ USDA-ARS, Hydrology and Remote Sensing Laboratory, 10300 Baltimore Ave., Bldg. 007, BARC-WEST, Beltsville, MD 20705, USA \\ ${ }^{4}$ USDA-ARS, Southwest Watershed Research Center, 2000 East Allen Rd, Tucson, AZ, 85719, USA
}

\begin{abstract}
:
Concerns for microbial safety of surface water facilitate development of predictive models that estimate concentrations and total numbers of pathogen and indicator organisms leaving manure-fertilized fields in overland flow during runoff events. Spatial variability of bacterial concentrations in applied manure introduces high uncertainty in the model predictions. The objective of this work was to evaluate the uncertainty in model predictions of the manure-borne bacteria overland transport caused by limited information on the spatial distribution of bacteria in surface-applied manure. Experiments were carried out at the ARS Beltsville experimental watershed site (OPE3) in Maryland. Dairy bovine manure was applied at a $59.3 \mathrm{t} / \mathrm{ha}$ rate on the 3.55 hectare experimental field. Faecal coliform (FC) concentrations in manure measured in 2004, 2005, 2007, and 2009 varied by 4 orders of magnitude each year. Both runoff volume and FC concentrations in runoff water were monitored using a runoff flume equipped with a refrigerated pump sampler. Two runoff events occurred before the manure was incorporated into the soil. A bacteria transport add-on module simulator of transport with infiltration and runoff (STWIR) was linked with the event-based kinematic runoff and erosion model (KINEROS2) to simulate convective-dispersive overland transport, bacteria release from manure, reversible attachment-detachment to soil, and surface straining of infiltrating bacteria. The model was successfully calibrated with the field experiment data. Monte Carlo simulations were carried out to account for the spatial variation in FC in applied manure and uncertainty in the FC distribution in manure caused by the small number of samples. A tenfold and twofold variation in FC concentrations in the runoff were obtained within the $90 \%$ probability interval when initial FC spatial distributions in the manure were represented by 5 and 29 samples, respectively. Copyright (C) 2011 John Wiley \& Sons, Ltd.
\end{abstract}

KEY WORDS bacteria; runoff; uncertainty; modelling

Received 8 July 2010; Accepted 12 January 2011

\section{INTRODUCTION}

Runoff from manure-fertilized fields is often considered the source of micro-organisms in surface water used for irrigation, recreation, and household needs. Concerns for microbial safety of this water have resulted in development of predictive models that estimate the concentrations and total numbers of pathogen and indicator organisms leaving manure-fertilized fields in overland flow during runoff events. Such models of bacteria fate and transport have been developed based on existing runoff, sediment, and chemical pollutant transport models or independently, and incorporated into watershed-scale water quality models. A brief list of models developed within the last two decades includes COLI (Walker et al.,1990), Hydrologic Simulation Program FORTRAN (HSPF) (Bicknell et al., 1997),

* Correspondence to: A. K. Guber, USDA-ARS, Environmental Microbial and Food Safety Laboratory, Bldg.173, Powder Mill Rd, BARCEAST, Beltsville, MD 20705, USA. E-mail: Andrey.Guber@ars.usda.gov
Spatially Explicit Delivery Model (SEDMOD) (Fraser, 1999), PROMISE and WATNAT (Medema and Schijven, 2001), Water Assessment Model with ArcView interface (WAMView) (Bottcher and Hiscock, 2001), Loading Simulation Program in C++ (LSPC) (Tetra Tech, Inc., 2002), Soil and Water Assessment Tool (SWAT) (Sadeghi and Arnold, 2002; Neitsch et al., 2005), and other models developed specifically for pastureland watersheds (Tian et al., 2002; Collins and Rutherford, 2004). Comprehensive reviews have been recently published (Jamieson et al., 2004; Coffey et al., 2007) to evaluate capability of models to predict the microbial quality of surface waters in rural watersheds. Jamieson et al. (2004) reviewed approaches used in the microbial transport models at watershed scale. They found that despite GIS-based models being useful in characterising the relative pollution potential in large spatially variable watersheds, recently developed physically based models are limited in their predictive capacities due to ignorance of critical inputs for bacteria transport processes. Specifically, 
the models do not account for bacteria transport with sediment particles and subsurface transport of microorganisms. Coffey et al. (2007) compared performance of 14 quantitative simulation models that could potentially be used for modelling bacterial pollutants in agricultural watersheds. The models were evaluated based on a set of criteria: type of model (qualitative or quantitative); treatment of input variables (stochastic or deterministic); use of input data (vector or raster); ability to incorporate various input factors; ability to produce output facilities; and overall model functionality. The authors concluded that despite the complexity of the processes included in the simulations the models were not able to account for all geological and hydrological factors affecting transport of bacteria in surface runoff.

The watershed-scale approach has received much attention in the development of microbial water quality modelling. One of the main reasons is regulatory requirements such as the Total Maximum Daily Load (TMDL), or TMDL program that was established to respond to the Clean Water Act of 1973 for nutrients and sediment as well as for microbial water contaminants. Bacterial modelling capabilities and limitations for setting TMDL limits have been recently evaluated for two widely used watershed models HSPF and SWAT (Benham et al., 2006). The HSPF was implemented to find a scenario that reduces the amount of bacteria applied to the land surface or directly deposited in the streams of Mill Creek watershed to meet Virginia State water quality standards. It has been shown in a series of HSPF simulations that the water quality standards cannot be met even with a $100 \%$ reduction from all non-wildlife bacteria source. The solution was found in $40 \%$ reduction in land-deposited wildlife loads. The SWAT model was applied to reduce FC concentrations in a 21-km-long segment of Shoal Creek in southwest Missouri. Septic tanks, poultry litter, grazing cattle, and wildlife were considered the sources of pollution. Several scenarios specifying different levels of bacteria source reduction were run in order to assess which suite of management practices would lead the stream meeting the applicable state's water quality criteria. The recommendation was to address the contamination from human sources, to eliminate cattle from the streams by providing alternative drinking sources, and implement buffers and filter strips.

Recently, the uncertainty in watershed-scale predictions of microbial water quality has come under increased scrutiny, in part because of the need for better estimations for the margin of safety component in TMDL assessments (Shirmohammadi et al., 2006). Previous studies that have conducted uncertainty analysis with various models reported the uncertainty of bacteria deposition rates as the predominant source of uncertainty in model predictions of the microbial stream water quality. For example, Paul et al. (2004) analysed the uncertainty of the HSPF model in predicting peak in-stream FC concentrations. They concluded that the major source of uncertainty was variability in the maximum amount of FCs at the land surface. Haydon and Deletic (2009) investigated the uncertainty in estimating E. coli loads to streams at three catchments in southern Australia. They found that random errors in bacteria deposition rates had the largest impact on uncertainty in the EG model output. These results were based on pathogen-removal models combining several fields into a single computational cell so that only variability in the total amount of manure applied in such a cell caused the uncertainty in results. Coffey et al. (2010) in their work at the watershed scale concluded that further research is required particularly in assessing the initial concentration of $E$. coli in human/animal waste. Oliver et al. (2009) indicated that appreciating inadequacies in baseline sampling to underpin model development and uncertainty in the magnitudes of microbial pollutants attributed to different faecal sources are among key issues with respect to scale-appropriate modelling of diffuse microbial pollution from agriculture.

Substantial uncertainty exists not only in total amount of bacteria deposited with manure but also in spatial distributions of deposited bacteria within the field. This variability can be very large partly because of the variations in bacteria concentration in manure. Patni et al. (1985) and Pachepsky et al. (2006) reported six orders of magnitude variation in E. coli concentrations in manure, and data distributions being highly asymmetrical. The summary of data on FCs concentrations in fresh dairy manure (ASAE, 1993) also confirms the high asymmetry of distributions and the standard deviations that are typically almost two times larger than the average values. It is not, however, known how such variability can affect the uncertainty in estimates of bacteria transport to the edge of the field. This type of uncertainty assessment has to be done at the field scale rather than at the watershed scale so that spatial distributions of manureborne bacteria can be explicitly simulated.

Most of recent efforts in studying bacterial transport were focused on the plot and watershed scales, whereas field-scale studies received relatively little attention. In most plot-scale experiments the effects of surface slope, vegetation, manure age, rainfall intensity, and duration on bacteria release and transport were studied in controlled conditions (Springer et al., 1983; Coyne and Blevins 1995; Tate et al., 2000; Edwards et al., 2000; Davies et al., 2004; Thurston-Enriquez et al., 2005; Soupir et al., 2006; Ferguson et al., 2007; Mishra et al., 2008; Guber et al., 2009b). Unlike plot-scale experiments, the watershed-scale studies were focused primarily on the effectiveness of the best management practices (BMPs) for minimising bacterial contamination of surface water (Kunkle, 1970; Buckhouse and Gifford, 1976; Doran and Linn, 1979; Gary et al., 1983; Patni et al., 1985). Datasets on overland transport of bacteria only rarely have been collected at agricultural fields of varying crop and soil management. For example, Abu-Ashour and Lee (2000) studied E. coli overland transport at field sites with 2 and $6 \%$ slopes during two runoff events after a biotracer application. In the first runoff event they observed E. coli in runoff at distances of 20 and $30 \mathrm{~m}$ 
from the application plots at 2 and $6 \%$ sites, respectively, whereas no E. coli were found in runoff during the second event. They concluded that zero $E$. coli concentrations in the second event were caused by bacteria die-off and infiltration into the soil. Harmel et al. (2010) measured E. coli content in runoff from grazed pastures and from cultivated fields ranging from 0.9 to 18.1 ha in size after dairy compost application. The compost application did not affect $E$. coli concentrations in runoff in their study. The authors did not enumerate E. coli in the applied compost and did not measure the temperature during composting process, but assumed that composting reduced $E$. coli in the manure to a negligible level. Collins et al. (2005) studied overland transport of E. coli from a sheep grazing field of about 1 ha in size using rainfall simulators. They found that event-average concentrations and total number of E. coli transported in runoff declined exponentially with the time elapsed since the last occurrence of sheep grazing. No attempt to simulate bacterial overland transport was undertaken in these studies.

Springer et al. (1983) were probably the first to have developed and validated a plot-scale process-based model of FC release from surface-applied manure and overland transport with runoff water. The Preliminary Nonpoint Source Transport Model for Indicator Bacteria computed overland water flow based on the kinematic wave equation, FC transport with runoff based on the convective-dispersion equation and $\mathrm{FC}$ exchange with the soil using the Freundlich isotherm. The authors calibrated their model on the experimental data of FC release and transport from aged manure at different irrigation rates and durations. However, the process of bacteria release from manure was not considered in the model. Wang et al. (1996) developed a mechanistic model of overland transport of manure constituents based on the sediment transport continuity equation, controlled by transport capacities of individual sediment particle size groups. The model was tested with the dataset obtained in rain simulation experiments on plots $1.5 \times 6.0 \mathrm{~m}$ in size (Edwards and Daniel, 1993). The simulated sum of manure and soil particles transported with runoff was fitted to the total suspended solids measured in the experiments. The manure erodibility was linearly related to the application rate in their study. Guber et al. (2009b) developed and tested a plot-scale mechanistic model of bacteria release and overland transport from surface-applied manure. The model included time and rainfall-controlled release of bacteria from surfaceapplied manure, straining of infiltrated bacteria, and bacteria attachment-detachment to solid phase. The model performed reasonably well for vegetated plots, but underestimated peaks of bacteria concentrations in bare plots.

Plot-scale experiments have been instrumental in assessing factors of the overland bacteria transport. However, it is far from clear how extendable are the results of these experiments to the field scale due to spatial and temporal variability of the studied factors. Therefore, there is a need for additional field-scale studies examining uncertainty of bacterial transport prediction associated with the variability of factors, and providing information for model parameter upscaling from plot to field scale. The objective of this study is to address the need in field-scale studies by examining uncertainty in model predictions of the manure-borne bacteria overland transport caused by limited information of the spatial distribution of bacteria in surface-applied manure.

\section{MATERIALS AND METHODS}

\section{Modelling overland water flow}

The kinematic runoff and erosion model (KINEROS2) (Woolhiser et al., 1990; Semmens et al., 2008; www. tucson.ars.ag.gov/kineros) was developed to simulate event-based runoff from small agricultural and urban watersheds. The model has been tested and used at scales ranging from a small plot to sub-catchments and watersheds. Durua et al. (1994) tested the model on a 30.4 ha watershed located near Treynor, Iowa. The calibrated model simulated the rainfall-runoff process with satisfactory accuracy. Model tests on a plot scale were performed for sandy loam and clayey loam soils in Beltsville, Maryland (Guber et al., 2009b). The model was successfully calibrated on runoff data obtained in a series of simulated rainfall experiments at vegetated and bare $2 \times 6 \mathrm{~m}$ plots. The model has been recently applied for estimation of the flood-prone territories in the Malki Iskar River basin (Nikolova et al., 2009) and for forecasting of the flash flood in a $6.4 \mathrm{~km}^{2}$ sub-catchment of Walnut Gulch (Yatheendradas et al., 2008).

The KINEROS2 model represents overland flow on an arbitrary-shaped watershed as one-dimensional flow within an equivalent rectangle. The model employs a power-law equation

$$
q=\alpha h^{m}
$$

where $h$ is the ponding depth, or storage of water per unit area (L), $q$ is the flux, or water discharge per unit width $\left(\mathrm{L}^{2} \mathrm{~T}^{-1}\right)$, and parameters $\alpha$ and $m$ represent surface properties, i.e. slope, roughness, and flow regime. These parameters were computed using the Chezy hydraulic resistance equation:

$$
\alpha=C S^{1 / 2} \quad \text { and } \quad m=3 / 2
$$

where $S$ is the surface slope, $\left(\mathrm{L} \mathrm{L}^{-1}\right)$ and $C$ is the Chezy friction coefficient for overland flow.

Equation (1) is used in conjunction with the mass conservation equation:

$$
\frac{\partial h}{\partial t}+\frac{\partial q}{\partial x}=R-I
$$

where $R$ is the precipitation rate $\left(\mathrm{L} \mathrm{T}^{-1}\right), I$ is the infiltration rate $\left(\mathrm{L} \mathrm{T}^{-1}\right), t$ is time $(\mathrm{T})$, and $x$ is the distance along the slope (L). 
The three-parameter infiltration equation (Parlange et al., 1982) is used in the KINEROS model for calculating infiltration rate into the soil:

$$
I=K_{\text {sat }}\left[1+\frac{\sigma}{\exp \left(\sigma I^{*} / B\right)-1}\right]
$$

where $K_{\text {sat }}$ is the saturated hydraulic conductivity (L $\left.\mathrm{T}^{-1}\right), \sigma$ is the dimensionless parameter that represents the soil type, $I^{*}$ is the infiltrated depth $(\mathrm{L}), B=(G+$ $h)\left(\theta_{s}-\theta_{i}\right), G$ is the net capillary drive (L), $\theta_{s}$ and $\theta_{i}$ are the soil water contents at saturation and initial condition $\left(\mathrm{L}^{3} \mathrm{~L}^{-3}\right)$, respectively.

\section{Modelling overland transport and removal of bacteria}

A plot-scale model has been recently developed and linked to the KINEROS2 model to simulate bacteria transport with overland flow and to evaluate uncertainty of coliform bacteria removal from vegetated filter strip (Guber et al., 2009b). A set of five equations including seven parameters described bacteria transport processes in the model:

- bacteria release from surface-applied manure;

- influx of bacteria from irrigation water;

- advective-dispersive transport of bacteria with runoff water;

- infiltration of bacteria into the soil;

- straining of micro-organisms from the infiltrating water by plant litter and vegetation layer;

- exchange of micro-organisms between runoff water and the mixing zone of soil at the surface;

- attachment and detachment of bacteria at the solid phase;

- bacteria die-off in manure, runoff water, soil mixing zone, and soil solid phase.

The plot-scale model was modified to describe bacteria overland transport at a field scale with fewer numbers of parameters and equations. The modified add-on module simulator of transport with infiltration and runoff (STWIR) was linked to the KINEROS2 model. The STWIR module employs the mass conservation equation for the bacteria cells in the runoff in the form:

$$
\begin{aligned}
& \frac{\partial h C_{r}}{\partial t}+\frac{\partial q C_{r}}{\partial x}=\frac{\partial}{\partial x}\left(a_{L} q \frac{\partial C_{r}}{\partial x}\right)-\frac{\partial S_{m}}{\partial t} \\
& -d\left(k_{a} C_{r}-k_{d} \rho S_{s}\right)-\left(1-k_{s}\right) I C_{r}+R C_{i r}
\end{aligned}
$$

where $a_{L}$ is the dispersivity (L), $d$ is the thickness of the mixing zone $(\mathrm{L})$, i.e. thickness of the soil surface layer that actively interacts with the overland flow, $C_{i r}$ and $C_{r}$ are cell concentrations in the irrigation and runoff water, respectively, $\left(\mathrm{M} \mathrm{L}^{-3}\right), S_{m}$ is the cell concentration in the manure applied to the soil surface $\left(\mathrm{M} \mathrm{L}^{-2}\right)$, and $S_{s}$ is the cell concentration in the solid phase of soil mixing zone $\left(\mathrm{M} \mathrm{M}^{-1}\right), k_{a}$ and $k_{d}$ are attachment and detachment rates of bacteria at the solid phase $\left(\mathrm{T}^{-1}\right)$, respectively, $\rho$ is the soil bulk density in mixing zone $\left(\mathrm{M} \mathrm{L}^{-3}\right)$, and $k_{s}$ is the straining coefficient.

The first and the second terms in the left-hand side of Equation (5) describe changes of bacteria concentration in the overland flow and the bacteria advection with the velocity calculated by Equation (1), respectively. In the right-hand side, the first term describes the bacteria dispersion assuming its linear dependence on the advective flux; the second term describes the change of bacteria concentration in the surface-applied manure; the third term accounts for the exchange of micro-organisms between runoff water and the soil mixing zone; and the fourth term simulates straining of micro-organisms from the infiltrating water by plant litter and vegetation. The coefficient $k_{s}\left(0 \leq k_{s} \leq 1\right)$ is the parameter that accounts for the rate of straining ( $k_{s}=0$ if no straining occurs, $k_{s}=1$ if bacteria are fully strained). Finally, the last term in Equation (5) describes the bacteria influx from irrigation water.

The mass conservation equation of bacteria in the soil mixing zone is:

$$
d \rho \frac{\partial S_{s}}{\partial t}=d\left(k_{a} C_{r}-k_{d} \rho S_{s}\right)+k_{f}\left(1-k_{s}\right) I C_{r}
$$

where $k_{f}$ is the fraction of infiltrated cells which are filtered out within the soil-mixing zone.

The left-hand side of Equation (6) describes change in bacteria concentration in the solid phase of the mixing zone; the first term in the right-hand side describes reversible attachment and detachment of bacteria to the solid phase in the mixing zone, while the second term accounts for bacteria filtering out from infiltrated water by soil solid phase.

The net release of bacteria from the surface-applied manure is assumed to be proportional to the precipitation rate:

$$
\frac{\partial S_{m}}{\partial t}=-C_{m} R
$$

where $C_{m}$ is the concentration of released bacteria calculated according to Bradford and Schijven model (2002):

$$
C_{m}(t)=\frac{C_{0} h_{m} \alpha_{m}}{R}\left(1+\alpha_{m} \beta_{m} t\right)^{-\left(1+1 / \beta_{m}\right)}
$$

where $h_{m}$ is the thickness of the applied manure (L), $\alpha_{m}$ $\left(\mathrm{T}^{-1}\right)$ and $\beta_{m}$ (dimensionless) are parameters defining the shape of the release curve, and $C_{0}$ is the initial content of bacteria cells in an applied manure $\left(\mathrm{M} \mathrm{L}^{-3}\right)$. Applicability of this model has been confirmed at different irrigation rates in field experiments in study of Guber et al. (2006), where values of $\alpha_{\mathrm{m}}$ were found closely related to the irrigation rate $R$ according to the linear regression equation

$$
\alpha_{m}=0.036+0.860 R, \mathrm{R}^{2}=0.988
$$

for the irrigation rates in the range from 2.51 to $6.93 \mathrm{~cm} \mathrm{~h}^{-1}$

Equations (1)-(8) were solved numerically using the implicit finite different scheme. Initial and boundary 
conditions were set as described below. The KINEROS2 numerical code (Woolhiser et al., 1990; Semmens et al., 2008) was used to solve the infiltration and runoff flow Equations (1)-(4). The boundary conditions of zero ponding depth at $x=0$, and the initial condition of $h=0$ for $x>0$ were used. The front limitation algorithm (Haefner et al., 1997) was applied to solve the bacteria transport Equations (5), (6), and (7). The Dirichlet boundary condition of zero concentration and the Neumann boundary condition of zero concentration gradient were set at the inlet and outlet boundaries, respectively, and a constant initial concentration $C_{r}=0$ at $x>0$ was assumed for Equation (5) at the absence of surface water.

\section{Field experiment}

Study of FC transport in overland flow after manure application was conducted at the OPE3 USDA-ARS research site (Beltsville, Maryland). The soil in the study area is classified as a coarse loamy, siliceous, mesic Typic Hapluddults (Gish and Kung, 2007). The soil profile consists of a coarse loamy sand in the top soil $(0-30 \mathrm{~cm}$ with organic matter content of $1-2 \%)$, underlain with a sandy loam $(30-80 \mathrm{~cm})$, a coarse sand $(80-150 \mathrm{~cm})$, and a gravelly sand in the lowest horizon $(150-250 \mathrm{~cm})$. The study area has been used for field corn production.

An H-flume $0.457 \mathrm{~m}$ deep was installed at the lowest point of the field to record runoff hydrographs (Figure 1). The flume was equipped with a SIGMA 900 MAX refrigerated sampler (Hach Co, Loveland, CO, USA) to collect runoff water for the bacterial analysis. The rationale for use of the refrigerated auto sampler was the ability to monitor events which last from 8 to $12 \mathrm{~h}$. The collection bottles were sterilized and installed several hours before forecasted rainfall to provide aseptic sampling. Precipitation was measured at a distance of approximately $100 \mathrm{~m}$ from the experimental field with a TE525 tipping-bucket rain gauge (Texas Electronics, Dallas, Texas). Rainfall which initiates runoff right after a manure application is a rare event for coarse, loamy, sandy soils in the studied area. Two runoff events occurred after intensive rainfalls on 2 May and 10 May 2004. Runoff events were not observed in the period of time between manure application and incorporation into the soil in 2005, 2007, and 2009.

Manure was collected annually from the same dairy and beef herd production centre in Beltsville, MD. Dairy manure was from heifers and dry cows with bedding consisting of primarily straw and corn stalks with small addition of sawdust. Beef manure was mostly scraped from outdoor feeding pads and contained mixed old hay and silage. Manure accumulation started in January and continued until application. Manure was typically applied in April or early May at a $59.3 \mathrm{t} / \mathrm{ha}$ application rate on the 3.55 ha experimental field (Figure 1). In 2004, 2005, 2007, and 2009, forty-six 20-g manure samples were taken randomly from the applied area and immediately after manure application to assess spatial variability of FC content in the applied manure.

In 2004, manure was applied with a New Holland manure spreader within $4 \mathrm{~h}$ on 2 May and incorporated into the soil on 12 May via a disc cultivator to preserve nutrients from loosing through runoff. Gravimetric water content and FC concentrations were measured in 25 soil samples taken randomly across the field from the upper $10 \mathrm{~cm}$ soil layer before the manure applications.

Collected manure, soil, and runoff samples were transported to the laboratory on ice and processed within $12 \mathrm{~h}$. The 1:100 soil-water dilution ratio was used to extract FC from soil and manure samples. FC concentrations were determined in runoff samples, soil, and manure extracts by plating $250 \mu \mathrm{l}$ sub-samples onto MacConkeys Agar and counted with an Autoplate 4000 spiral platter (Spiral Biotech, Bethesda, MD). The sub-sample volume

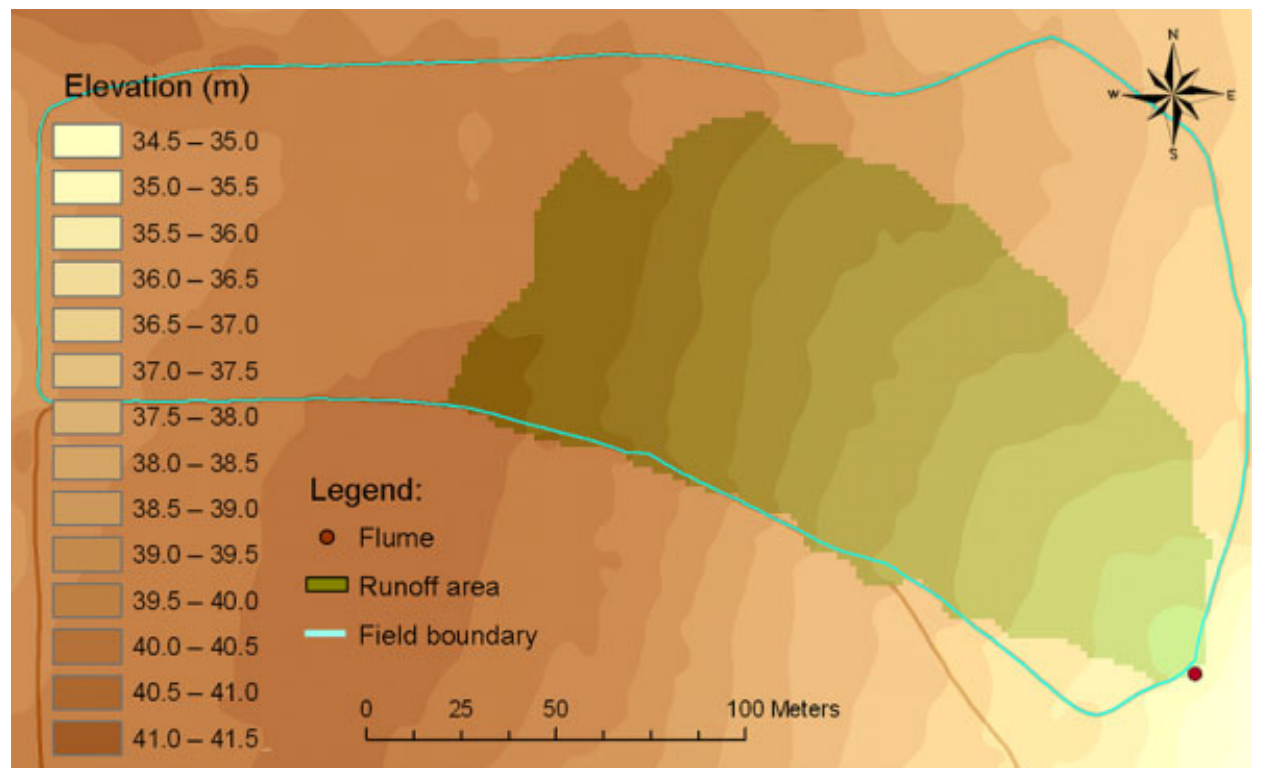

Figure 1. Digital elevation map of the study area 
was found empirically and provided reliable counts for the bacteria concentration range used in the study. After overnight incubation at $44.5^{\circ} \mathrm{C}$, pink-to-red colonies were counted using a Protocol plate reader (Synoptics, Cambridge, UK) to obtain the number of presumptive FC. The FC counts were expressed as colony-forming units (CFU).

\section{Model calibration}

The Arc/Info GIS hydrologic modelling tool Watershed was applied to a raster grid of the surface elevation to delineate the upslope area contributing flow to the flume (Figure 1). The delineated area of 1.60 ha was represented in the KINEROS2 model as a $84.1 \times 190.0 \mathrm{~m}$ rectangular planar overland flow domain with a slope of $2.7 \%$ toward the flume to simulate $\mathrm{FC}$ transport with overland flow.

The overland flow component of KINEROS2 was calibrated for each event separately. PEST software (Doherty, 2005) was used to solve the inverse problem of minimising the root mean square error between the observed and simulated cumulative discharge. The fitto-cumulative discharge data assured correctness of total water amount passing the flume within each runoff event. The boundary condition of $h=0$ at $x=0$ was used. The Chezy friction coefficient $(C)$, the saturated hydraulic conductivity $\left(K_{\text {sat }}\right)$, the net capillary drive $(G)$, and the parameter $\sigma$ were obtained by the KINEROS 2 calibration on the experimental runoff data.

The transport component of STWIR was calibrated using measured FC concentrations in the runoff water. The thickness of the soil mixing zone was adopted from SWAT model (Sadeghi and Arnold, 2002) and set to $1 \mathrm{~cm}$. The STWIR parameters $a_{L}, k_{a}, k_{d}, k_{s}, k_{f}$, and $\beta_{m}$ were obtained by the STWIR calibration on the FC concentrations observed on 10 May, then the model was validated on data measured on 2 May 2004. Root mean square errors (RMSE), the Nash-Sutcliffe efficiency, and Pearson correlation coefficients between measured and simulated data were used to assess the model performance.

\section{Monte Carlo simulations}

Four main sources of uncertainty are typically considered in the hydrologic modelling (Renard et al., 2010). They are:

- input uncertainty, e.g. sampling and measurement errors in catchment rainfall estimates;

- output uncertainty, e.g. rating curve errors affecting runoff estimates;

- structural uncertainty (sometimes referred to as 'model uncertainty'), arising from lumped and simplified representation of hydrological processes in hydrologic models;

- parametric uncertainty, reflecting the inability to specify exact values of model parameters due to finite length and uncertainties in the calibration data, imperfect process understanding, model approximations, etc.
The uncertainty of bacteria overland transport associated with uncertainty in transport parameters, rainfall intensity, and duration has been already studied in assessment of vegetation filter strip efficiency (Guber et al., 2009b). This paper focuses solely on the effects of uncertainties in FC distribution in the applied manure on the results of simulations. The specific goal of this study was to analyse two sources of uncertainties: (i) spatial variability in FC content in the applied manure; and (ii) errors in estimated probability distribution function (PDF) of FC in manure associated with the number of manure samples.

For this reason, we used calibrated and validated model with rainfall event, which produced high FC concentrations in runoff water.

To evaluate the first source of uncertainty, FC concentrations measured in 46 manure samples were randomly distributed across the field. Initial conditions for FC transport simulation were:

$$
\begin{gathered}
S_{s}(x, 0)=0 \\
S_{m}(x, 0)=10^{y}
\end{gathered} \quad F(y)=\left\{\begin{array}{cc}
0 & y<a \\
\frac{y-a}{b-a} & a \leq y<b \\
1 & y \geq b
\end{array}\right.
$$

where $a$ and $b$ were minimum and maximum values of uniform PDF of the logarithm of FC concentrations in the applied manure across the field, $y$ was logarithm of FC concentrations randomly sampled from uniform PDF. The Monte Carlo simulation was repeated 100 times using the calibrated parameters of the STWIR model and precipitation observed on 10 May 2004. Results of the simulations were presented as the percentage of the total FC in manure that was transported with runoff to the edge of the field.

To account for the second source of uncertainty, the smaller numbers of samples were used to represent FC distribution in the applied manure. The sub-sets of 5, $7,9, \ldots 29$ samples were drawn randomly from 46 measured manure samples. Then the PDF parameters $a$ and $b$ (Equation (10)) were derived based on the data from each sub-set. These distribution functions were used in the Monte Carlo simulations as described above. A total of 50 random selections were made for each number of samples (5-29) and 100 simulations were done for each number of samples as described in the previous paragraph. Simulation results were integrated to present and compare the average FC concentrations in the applied manure and the percentages of the total FC in manure that were transported with runoff to the edge of the field.

\section{RESULTS AND DISCUSSION}

\section{Spatial variability in $F C$ concentrations}

High variability of $\mathrm{FC}$ concentrations was observed in the applied manure. FC concentrations varied by 2, 3.5, 3.6 , and 4.4 orders of magnitude in 2004, 2005, 2007, and 2009 , respectively. The distributions of FC concentrations in applied manure were lognormal for data measured in 2005 and 2007, but were not lognormal in 2004 and 
2009. The geometric means were found to represent the median values reasonably well, whereas the average concentrations were from 5 to 30 times larger than median values in different years of sampling (Table I). The smallest median FC concentration of $1.8 \cdot 10^{4} \mathrm{CFU}$ $\mathrm{g}^{-1}$ observed in 2005 was about 6 times less than the largest median concentration of $1 \cdot 1 \cdot 10^{5} \mathrm{CFU} \mathrm{g}^{-1}$ observed in 2007.

\section{Runoff water monitoring}

Two runoff events were observed during and after intensive rainfalls in May 2004. Total precipitation of 15.5 and $21.1 \mathrm{~mm}$ resulted in totals of 0.047 and
$1.41 \mathrm{~mm}$ of runoff on 2 May and 10 May 2004, respectively (Figure 2). The average rainfall intensity on 2 May $\left(3.88 \mathrm{~mm} \mathrm{~h}^{-1}\right)$ was 3.6 times less than the average intensity on 10 May $\left(14.1 \mathrm{~mm} \mathrm{~h}^{-1}\right)$. Temporal rainfall patterns affected the shape of the runoff hydrographs. The cumulative runoff was gradually increasing during the rainfall on 2 May, and runoff ceased almost simultaneously with the rainfall. For the 10 May event, the runoff hydrograph was steep, and runoff continued for nearly $3 \mathrm{~h}$ after the rainfall ceased. Runoff constituted a very small part of total precipitation in the observed events which was expected, given the sandy texture of the studied soil. Short intensive rainfall on 10 May resulted in earlier initiation of runoff and relatively large proportion of rainwater running off as

Table I. Statistics of FC content in the applied manure expressed on wet weight basis

\begin{tabular}{cccccc}
\hline Year & Min & Max & Mean & Median & Geometric mean \\
\hline & $10^{4} \mathrm{CFU} \mathrm{g}^{-1}$ & $10^{6} \mathrm{CFU} \mathrm{g}^{-1}$ & $10^{5} \mathrm{CFU} \mathrm{g}^{-1}$ & $10^{5} \mathrm{CFU} \mathrm{g}^{-1}$ & $10^{5} \mathrm{CFU} \mathrm{g}^{-1}$ \\
2004 & $1 \cdot 0$ & $1 \cdot 10$ & 2.45 & $0 \cdot 55$ & $0 \cdot 77$ \\
2005 & $0 \cdot 0$ & 1.35 & 1.02 & $0 \cdot 18$ & $0 \cdot 22$ \\
2007 & $0 \cdot 4$ & $15 \cdot 1$ & $11 \cdot 1$ & $1 \cdot 07$ & $1 \cdot 32$ \\
2009 & $0 \cdot 0$ & $27 \cdot 7$ & $13 \cdot 8$ & 0.45 & $0 \cdot 74$ \\
\hline
\end{tabular}
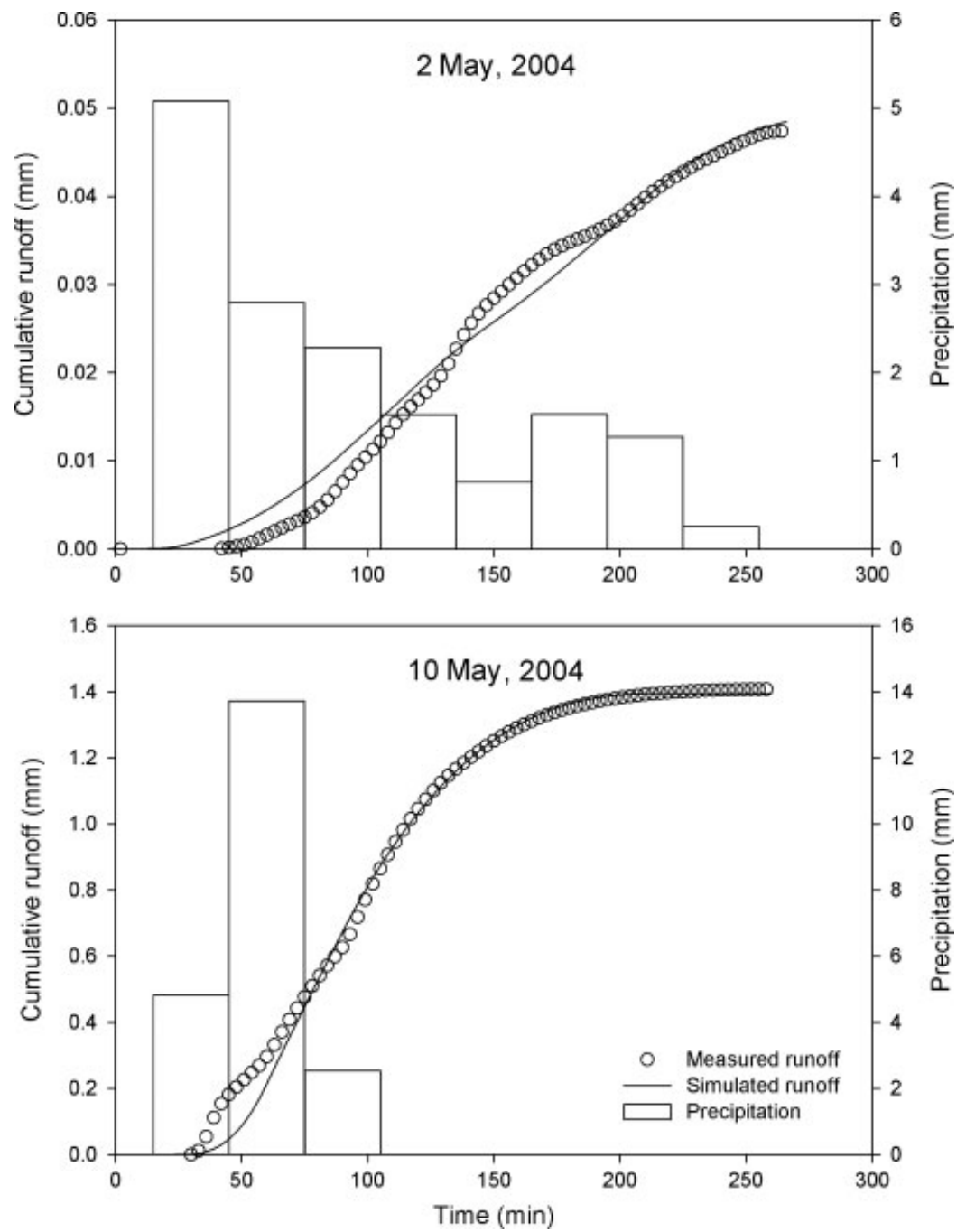

Figure 2. Results of the KINEROS2 model calibration on cumulative runoff data measured on 2 and 10 May 2004 
compared with less intensive gradually subsiding rainfall on 2 May 2004. The FC concentrations in runoff measured at the same times from the beginning of the runoff were one order of magnitude less in the 2 May event compared to 10 May 2004 (Figure 3). Higher rainfall intensity caused larger numbers of bacteria cells released from the manure and faster overland transport toward the flume.

\section{Model calibration}

The hydraulic component of the KINEROS2 model (Equations (1)-(4)) was calibrated for runoff events observed on 2 May and 10 May 2004. The model after calibration performed satisfactorily as shown in Figure 2. Values of RMSE for the cumulative runoff were 0.002 and $0.042 \mathrm{~cm}$; Pearson correlation coefficients between measured and simulated data were 0.994 and 0.998 in the two events, respectively (Table II). Calibrated values of the hydraulic parameters are presented in Table III. Values of parameters in the infiltration Equation (4) differed considerably for two events indicating dissimilarity in infiltration regimes. The decrease in infiltration rate was gradual within $2.5 \mathrm{~h}$ of the first event, but was sharp during the first half hour and ceased one hour after the start of the rainfall in the second event. These differences were likely caused by the alteration of soil surface during the intensive rainfall on 10 May $2004\left(14.1 \mathrm{~mm} \mathrm{~h}^{-1}\right)$. The droplet impact on soil surface increases with the rainfall
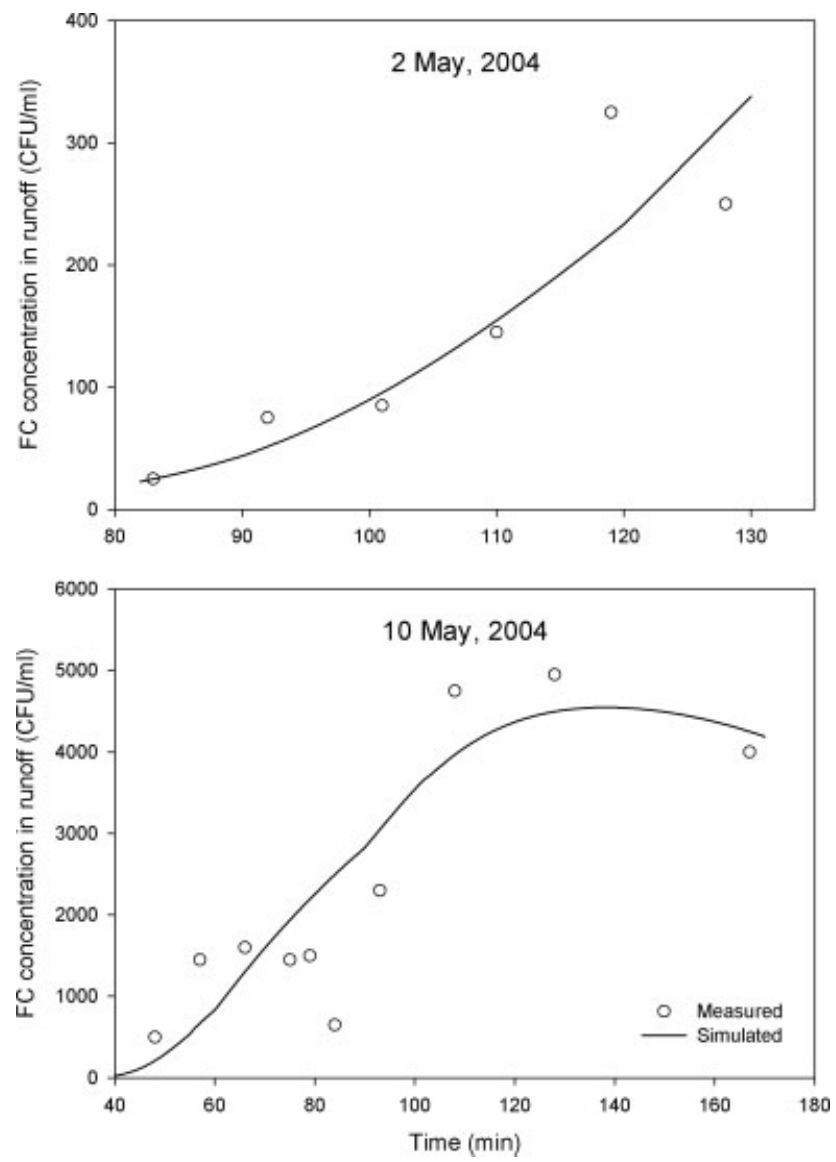

Figure 3. Results of the STWIR model calibration on FC concentration data measured in runoff water on 2 and 10 May 2004 rate and is likely to result in seal formation and macropore sealing that reduces hydraulic conductivity (Bruce and Whisler, 1973; Gimenez et al., 1992) and becomes the infiltration-limiting factor (Epstein and Grant, 1973).

The FC transport model STWIR (Equations (5)-(8)) was calibrated with the data observed on 10 May and then validated for the 2 May 2004 runoff event. The straining coefficients $k_{s}$ and $k_{f}$ approached the value of 1 during the calibration process. This lead to the conclusions that the parameters $k_{s}$ and $k_{f}$ should be excluded from calibration because the model predicted that bacteria remained suspended or became adsorbed after release from the manure and did not infiltrate in appreciable amounts. Both calibration and validation resulted in the satisfactory performance of the STWIR model (Figure 3). Relatively small RMSE, high values of the Nash-Sutcliffe efficiency and high correlation coefficients (Table II) indicated ability of the model to simulate FC transport with overland flow. The fitted parameter values were: the dispersivity $a_{L}=3.53 \mathrm{~m}$, the attachment and detachment FC rates $k_{a}=0.613 \mathrm{~h}^{-1}$ and $k_{d}=0.005 \mathrm{~h}^{-1}$, the straining coefficients $k_{s}=k_{f}=1$, and the FC release parameter $\beta_{m}=0 \cdot 150$.

The KINEROS2 and STWIR model performed well in this study. The closeness of the transport parameter values obtained in simulations of two substantially different rainfall-runoff events is encouraging, but requires further investigation to establish possible ranges of fitted transport parameters.

The calibrated bacteria attachment rate was substantially larger than the detachment rate. To evaluate this finding, we note that at the equilibrium the term $\left(k_{a} C_{r}-\right.$ $k_{d} \rho S_{s}$ ) in Equation (5) equals to zero and, therefore, the ratio $k_{a} /\left(k_{d} \rho\right)$ is equal to the partitioning coefficient $K$ in the linear attachment isotherm equation:

$$
C_{r}=K S_{s}
$$

Table II. Performance statistics of the KINEROS2 and STWIR models

\begin{tabular}{lcc}
\hline Statistics & 2 May 2004 & 10 May 2004 \\
\hline RMSE $_{\text {runoff }}(\mathrm{cm})$ & 0.002 & 0.041 \\
$R_{\text {runoff }}(P<0.05)$ & 0.994 & 0.998 \\
RMSE $_{\mathrm{FC}}\left(\mathrm{CFU} \mathrm{ml} \mathrm{ml}^{-1}\right)$ & 50.4 & 796.9 \\
$R_{\mathrm{FC}}(P<0.05)$ & 0.883 & 0.866 \\
Nash-Sutcliffe efficiency for FC & 0.769 & 0.740 \\
\hline
\end{tabular}

Root mean square errors (RMSE) and Pearson product moment correlation coefficients $(R)$ are given for the cumulative runoff, while RMSE, $R$ and the Nash-Sutcliffe efficiency are given for FC concentrations in the runoff.

Table III. Calibrated parameters of the KINEROS2 model

\begin{tabular}{lcc}
\hline Parameters and statistics & 2 May 2004 & 10 May 2004 \\
\hline$K_{\text {sat }}\left(\mathrm{cm} \mathrm{h}^{-1}\right)$ & 1.72 & 4.83 \\
$G(\mathrm{~cm})$ & 30.6 & $10 \cdot 0$ \\
$\sigma$ & 0.19 & $1 \cdot 00$ \\
$C$ & 0.03 & 0.29 \\
\hline
\end{tabular}


Values of $K$ between 100 and $1000 \mathrm{ml} \mathrm{g}^{-1}$ have been found in the experiments with the attachment of FC to clay, silt, and sand particles with organic coating (Guber et al., 2007). Values of $K$ between 20 and $2000 \mathrm{ml} \mathrm{g}^{-1}$ were found from data on $E$. coli partitioning between runoff and sediment in 1-h experiments on the rainfallinduced $E$. coli release from a bovine manure strip placed on the top of 6-m-long bare plots having 20\% slope and either sandy loam or silt (Pachepsky et al., 2006). Therefore, the two-order-of-magnitude difference between $k_{\mathrm{a}}$ and $k_{\mathrm{d}}$ is in general agreement with equilibrium data on coliform partitioning between soil and bacteria suspensions.

The best model prediction was obtained with the straining coefficient $k_{\mathrm{s}}$ equal to one. There are two terms in Equation (5) that control loss of bacteria in the mixing zone: $d k_{a} C_{r}$ and $\left(1-k_{s}\right) I C_{r}$. The value of $k_{\mathrm{s}}=1$ indicates that the infiltration rate does not affect the bacteria losses, and the kinetic attachment is the sufficient approximation of the bacteria exchange between the runoff and soil. Similar results were obtained earlier in FC transport simulations for sandy loam vegetated plots in runoff experiments with controlled irrigation rates (Guber et al., 2009b) where values of $k_{s}$ ranged from 0.9 to 0.96 .

\section{Effect of the spatial variability in FC concentrations}

The uncertainty of the FC prediction in runoff water related to the $\mathrm{FC}$ concentrations in the manure was assessed through a set of simulations with the rainfall pattern of the event observed on 10 May 2004. The calibrated model was run: (a) with constant FC concentrations in the applied manure across the field; and (b) in Monte Carlo simulations with random variable FC concentrations across the field. The constant FC concentrations were set equal to the average value, to the median value, and to the geometric mean value of the PDF of the $\log (\mathrm{FC})$ concentrations measured in manure in 2004 (Figure 4). For Monte Carlo simulations with random variable FC concentrations, parameters of the uniform and normal distributions were derived from fitting to the $\log (\mathrm{FC})$ concentrations measured in the manure in 2004 (Figure 4). The goodness-of-fit was estimated using Pearson product moment correlation coefficients $R$. Better agreement between fitted and measured data were obtained using a uniform distribution. The values of $R$ were 0.977 and 0.867 at probability $P<0.05$ for uniform and normal distributions, respectively. The variable initial concentrations were randomly derived for each of 190 field segments (each segment $84 \mathrm{~m}$ wide and $1 \mathrm{~m}$ long) using derived parameters $a$ and $b$ (Equation (10)) of the uniform PDF of the log (FC) concentrations measured in manure in 2004 (Figure 4). The total amount of FC at the edge of the field was calculated using the calibrated model.

Spatial variability in FC concentrations obtained in 100 generated distributions of FC resulted in considerable uncertainty of the simulation (Figure 5). Total FC contents in the runoff ranged from 0.009 to $0.020 \%$ of the

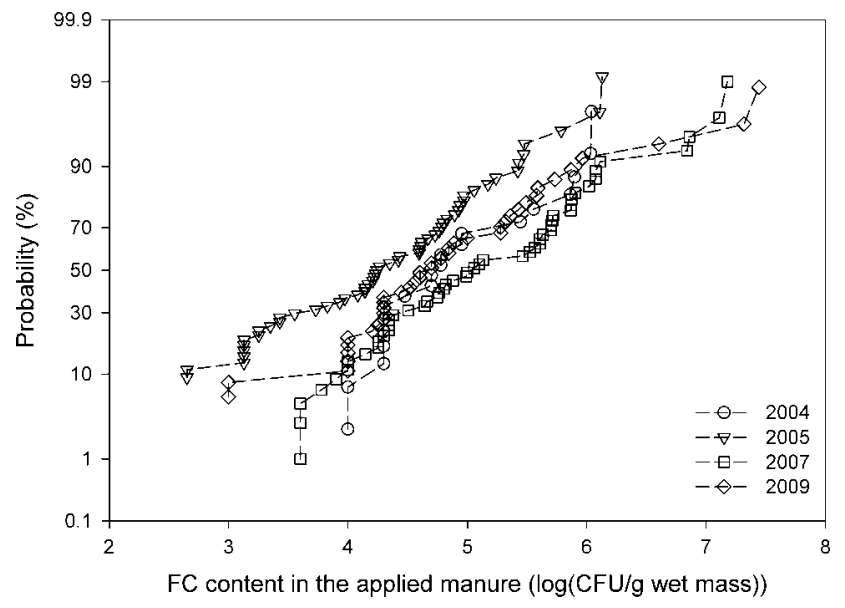

Figure 4. Empirical probability distribution functions of FC concentrations in manure applied in different years

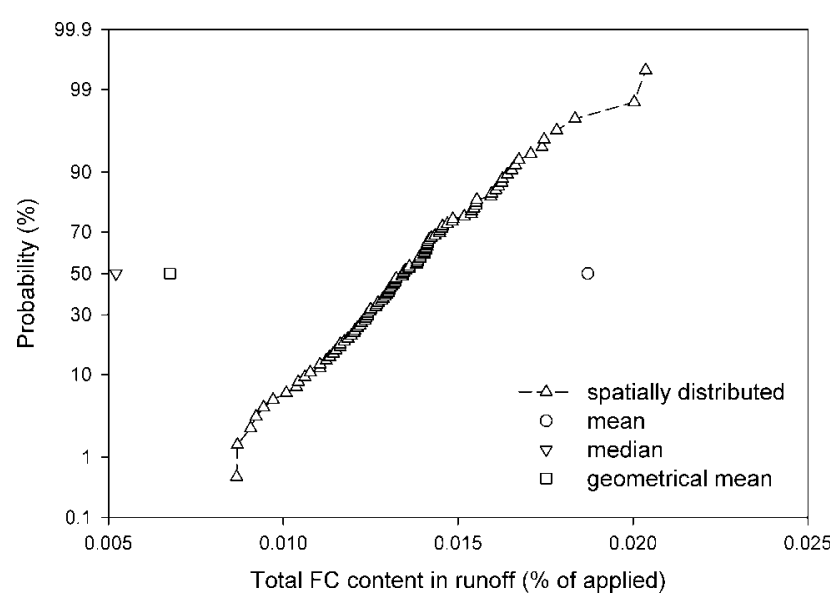

Figure 5. Simulated FC contents in runoff water with constant across the field (mean, median, and geometrical mean) and spatially distributed FC concentrations in the applied manure

applied amount. Results of simulations using single initial FC concentrations in the manure, i.e. mean, median, and geometric mean, corresponded to the extremes of the simulations using spatially distributed values (Figure 5). In particular, simulation with the mean initial FC concentration across the field grossly overestimated FC content in the runoff and corresponded to probability $P=97.7 \%$ of the results obtained with spatially distributed initial FC concentrations. However, simulations with median and geometrical mean concentrations substantially underestimated FC content in runoff and corresponded to probability $P<0.5 \%$ of the spatially distributed initial FC concentration results.

Results of our four-year survey of statistical distributions of FC concentrations in manure across the field (Figure 4) supported literature reports on high variability and the dominance of relatively small concentrations with occasional hot spots leading to the lognormal distributions (Patni, 1985; ASAE, 1993). The variability was most likely caused by the differences in the storage time and general variation in manure material. Weather conditions probably affected inter-annual differences in FC concentrations. On average, more FC survived in 2007 
which had the coldest winter among the study years and could have the highest $E$. coli survival rate because of the slow FC die-off at low temperatures. The geometric means represented median values reasonably well which is typical for distributions close to lognormal (Figure 4).

The Monte Carlo simulations with the uniform distribution of the $\log (\mathrm{FC})$ concentrations in applied manure resulted in the close to normal distribution of the fraction of FC recovered in runoff (Figure 5). The runoff seems to smooth away the effect of hot spots in concentrations. Using average FC concentrations lead to substantial overestimation of the FC fraction reaching the edge of the field. A similar conclusion was reached in the study of the phosphorus loss in runoff from soils (Penn et al., 2007). Experimental rainfall simulations in Penn et al. (2007) study showed that the use of an average $P$ value for an entire field can result in an inaccurate estimation of $P$ losses to surface waters. Figure 5 shows that the median value of the recovered FC fraction can be obtained if the initial FC concentration across the field is set at some level between mean and median. However, this level may be event and model parameter-specific.

\section{Uncertainty in simulation results caused by the uncertainty in FC distribution in manure}

The effect of the number of manure samples on the average $\mathrm{FC}$ concentration in manure and on the percentage of FC reaching the edge of field is shown in Figure 6. A substantial uncertainty related to the number of manure samples was encountered (Figure 6(a)). In case of 5 samples, the $90 \%$ probability interval of FC concentration in the runoff ranged from $2.6210^{8}$ to $3.5710^{9} \mathrm{CFU} \mathrm{m}^{-2}$, a tenfold difference (Figure 6(a)). Even when 29 samples were drawn, the $90 \%$ probability interval ranged from $1.2610^{9}$ to $2.3910^{9} \mathrm{CFU} \mathrm{m}^{-2}$, a twofold difference. A similar uncertainty was found in the percentage of FC recovered in runoff (Figure 6(b)). Results in this figure indicate that at least 15-20 samples were needed to correctly represent the uncertainty related to the uncertainty in applications.

Currently, observations of manure-borne bacteria transport are much less numerous than data on transport of other manure-borne contaminants. This translates to a relatively smaller knowledge base compared, for example, with phosphorus transport modelling (e.g. Kruger et al., 2007). However, the importance of the modelling uncertainty analysis established with other pollutants remains valid in modelling of manure-borne pathogen and indicator bacteria transport. Awareness of uncertainty, and how to determine its effects on modelling results, is the precondition for optimisation of resource allocation in data collection for model forcing, initialisation, calibration, and validation (Shirmohammadi et al., 2006). Partitioning modelling uncertainty between its sources shows directions of reducing the uncertainty attributed to that source. Setting the practical limits of model accuracy prevents overvaluing modelling results, and may lead to the search of better models, to the concurrent use of several models (Guber et al., 2009a), or to using other sources of
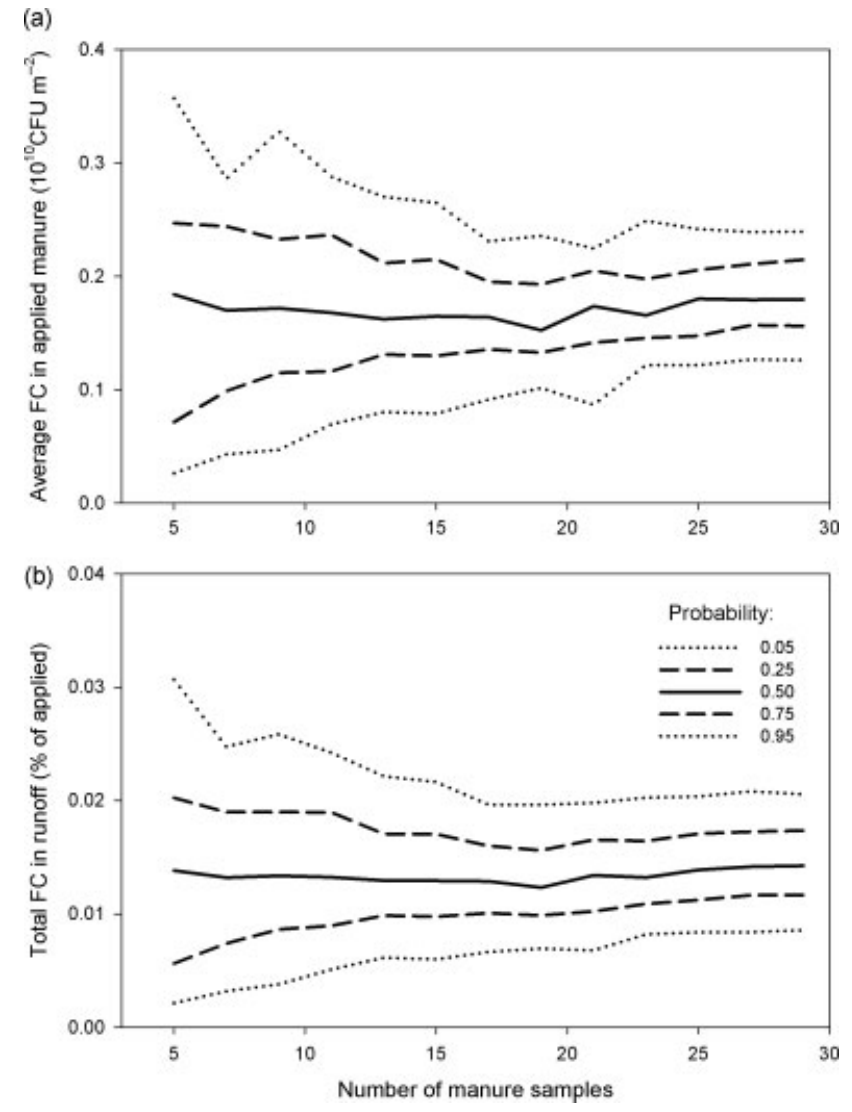

Figure 6. Average FC content in the applied manure and simulated FC content in runoff water obtained from Monte Carlo simulations with initial FC concentrations randomly drawn from empirical distributions obtained from different numbers of samples

judgment, such as expert panels. The quantitative microbial risk assessment (QMRA) in surface water use for recreation and irrigation currently recognizes the need in Monte Carlo simulations in exposure assessment (Mara and Sleigh, 2010) which in turn presumes the estimation of the uncertainty in microbial loads. Finally, Shirmohammadi et al. (2006) note that presenting management scenarios to the public along with the costs and probability of meeting specific water quality standards for each scenario would give the stakeholders a basis for deciding which scenarios they prefer. Manure management strongly affects micro-organism content and distribution in manure, and effects of the manure management on the uncertainty in pathogen and indicator bacteria transport from manure-fertilized fields presents an important avenue for further research.

\section{CONCLUSIONS}

Spatial variation of FC concentrations in applied manure resulted in uncertain model predictions of the manureborne bacteria overland transport. The magnitude of this uncertainty was evaluated using the overland microorganism transport model, STWIR, derived in conjunction with the rainfall-runoff model KINEROS2. The model was successfully calibrated and validated with the field experimental data. Monte Carlo simulations showed 
that using average FC concentrations lead to substantial overestimation of the FC fraction reaching the edge of the field. Inaccurate representation of bacteria concentrations in manure with a small number of samples substantially distorted estimates of bacteria loss from the field in runoff. Effects of the manure management on the uncertainty in pathogen and indicator bacteria transport from manure-fertilized fields present an important avenue for further research.

\section{REFERENCES}

Abu-Ashour J, Lee H. 2000. Transport of bacteria on sloping soil surfaces by runoff. Environmental Toxicology 15(2): 149-153.

ASAE. 1993. Manure Production and Characteristics. ASAE Standard D384.1 DEC93 . American Society of Agricultural Engineers: St. Josef, Michigan.

Benham BL, Baffaut C, Zeckoski RW, Mankin KR, Pachepsky YA, Sadeghi AM, Brannan KM, Soupir ML, Habersack MJ. 2006. Modeling bacteria fate and transport in watersheds to support TMDLs. Transactions of the ASABE 49: 987-1002.

Bicknell BJ, Imhoff J, Kittle JR, Donigan A, Johanson R. 1997. Hydrological simulation program FORTRAN. User's Manual for Version 11. EPA/600/R-97/080. National Exposure Research Laboratory. Research Triangle Park NC. USEPA.

Bottcher AB, Hiscock JG. 2001. WAMView-A GIS/land primary source of bacteria and pathogens on agricul-source based approach to watershed assessment modelling. In Proceedings of the TMDL Science Issues Conference, St. Louis, MO, USA. March 2001: 112-123.

Bradford SA, Schijven J. 2002. Release of Cryptosporidium and Giardia from dairy calf manure: Impact of solution salinity. Environmental Science and Technology 36: 3916-3923.

Bruce RR, Whisler FD. 1973. Infiltration of water into layered field soils. In Physical aspects of soil, water and salts in ecosystems, Hadas $\mathrm{H}$, Swartzendruber D, Rijtema PE, Fuchs M, Yaron D (eds), Ecological studies, V.4, Springer-Verlag: Berlin and New York; 77-89.

Buckhouse JC, Gifford GF. 1976. Water quality implications of cattle grazing on a semi-arid watershed on Southeastern Utah. Journal of Range Management 29(2): 109-113.

Coffey R, Cummins E, Cormican M, O'Flaherty V, Kelly S. 2007. Microbial exposure assessment of waterborne pathogens. Human and Ecological Risk Assessment 13: 1313-1351.

Coffey R, Cummins E, Bhreathnach N, Flaherty VO, Cormican M. 2010. Development of a pathogen transport model for Irish catchments using SWAT. Agricultural Water Management 97: 101-111.

Collins R, Rutherford K. 2004. Modelling bacterial water quality in streams draining pastoral land. Water Research 38(3): 700-712.

Collins R, Elliott S, Adams R. 2005. Overland flow delivery of faecal bacteria to a headwater pastoral stream. Journal of Applied Microbiology 99: 126-132.

Coyne MS, Blevins RL. 1995. Fecal bacteria in surface runoff from poultry-manure fields. In Animal waste and the land water interface, Steele K (ed.). Lewis Publisher: Boca Raton, FL; pp. 77-87.

Davies CM, Ferguson CM, Kaucner C, Krogh M, Altavilla N, Deere DA, Ashbolt NJ. 2004. Dispersion and transport of Cryptosporidium Oocysts from fecal pats under simulated rainfall events. Applied and Environmental Microbiology 70(2): 1151-1159.

Doherty J. 2005. PEST: Software for model-independent parameter estimation. Watermark Numerical Computing: Australia.

Doran JW, Linn DM. 1979. Bacteriological quality of runoff water from pastureland. Applied and Environmental Microbiology 37(5): 985-991.

Durua JO, Hjelmfelt AT Jr. 1994. Investigating prediction capability of HEC-1 and KINEROS kinematic wave runoff models. Journal of Hydrology 157: 87-103.

Edwards DR, Daniel TC. 1993. Effects of poultry litter application rate and rainfall intensity on quality of runoff from fescue grass plots. Journal of Environmental Quality 22(2): 361-365.

Edwards DR, Larson BT, Lim TT. 2000. Runoff nutrient and fecal coliform content from cattle manure application to fescue plots. Journal of the American Water Resources Association 36(4): 711-720.

Epstein E, Grant WJ. 1973. Soil crust formation as affected by raindrop impact. In Physical aspects of soil, water and salts in ecosystems, Hadas H, Swartzendruber D, Rijtema PE, Fuchs M, Yaron D (eds),
Ecological studies, V.4, Springer-Verlag: Berlin and New York; 195-201.

Ferguson CM, Davies CM, Kaucner C, Krogh M, Rodehutskors J, Deere DA, Ashbolt NJ. 2007. Field scale quantification of microbial transport from bovine faeces under simulated rainfall events. Journal of Water and Health 5: 83-95.

Fraser RH. 1999. SEDMOD: A GIS-Based Delivery Model for Diffuse Source Pollutants. Ph.D. dissertation. Yale University, New Haven, CT, USA.

Gary HL, Johnson SR, Ponce SL. 1983. Cattle grazing impact on surface water quality in a Colorado Front Range stream. Journal of Soil and Water Conservation 38(2): 124-128.

Gimenez D, Diren C, Miedema R, Eppink LAAJ, Schoonderbeek D. 1992. Surface sealing and hydraulic conductances under varyingintensity rains. Soil Science Society of America Journal 56: 234-242.

Gish TJ, Kung K-JS. 2007. Procedure for quantifying a solute flux to a shallow perched water table. Geoderma 138(1-2): 57-64.

Guber AK, Shelton DR, Sadeghi AM, Sikora LJ, Pachepsky YA. 2006. Rainfall-induced release of fecal coliforms, chloride, phosphorus and organic carbon from surface-applied dairy manure. Applied and Environmental Microbiology 72: 7531-7539.

Guber AK, Pachepsky YA, Shelton DR, Yu O. 2007. Effect of bovine manure on fecal coliform attachment to soil and soil particles of different sizes. Applied and Environmental Microbiology 73: 3363-3370.

Guber AK, Pachepsky YA, van Genuchten MTh, Simunek J, Jacques D, Nemes A, Nicholson TJ, Cady RE. 2009a. Multimodeling multimodel simulation of water flow in a field soil using pedotransfer functions. Vadose Zone Journal 8: 1-10.

Guber AK, Yakirevich AM, Sadeghi AM, Pachepsky YA, Shelton DR. 2009b. Uncertainty evaluation of coliform bacteria removal from vegetated filter strip under overland flow condition. Journal of Environmental Quality 38: 1636-1644.

Haefner F, Boy S, Wagner S, Behr A, Piskarev V and Palatnik V. 1997. The 'front limitation' algorithm a new and fast finite-difference method for groundwater pollution problems. Journal of Contaminant Hydrology 27: 43-61.

Harmel RD, Karthikeyan R, Gentry T, Srinivasan R. 2010. Effects of agricultural management, land use, and watershed scale on E. coli concentrations in runoff and streamflow. Transactions of the ASABE 53(6): 1833-1841.

Haydon S, Deletic A. 2009. Model output uncertainty of a coupled pathogen indicator-hydrologic catchment model due to input data uncertainty. Environmental Modelling and Software 24: 322-328.

Jamieson R, Gordon R, Joy D, Lee H. 2004. Assessing microbial pollution of rural surface waters: A review of current watershed scale modeling approaches. Agricultural Water Management 70: 1-17.

Krueger T, Freer J, Quinton JN, Macleod CJA. 2007. Processes affecting transfer of sediment and colloids, with associated phosphorus, from intensively farmed grasslands: a critical note on modelling of phosphorus transfers. Hydrological Process 21: 557-562.

Kunkle SH. 1970. Concentrations and cycles of bacterial indicators in farm surface runoff. In: Relationship of agriculture to soil and water pollution, Cornell university conference on agricultural waste management: Rochester, New York; pp. 49-60.

Mara D, Sleigh A. 2010. Estimation of norovirus and Ascaris infection risks to urban farmers in developing countries using wastewater for crop irrigation. Journal of Water and Health 8: 572-576.

Medema GJ, Schijven JF. 2001. Modelling the sewage discharge and dispersion of Cryptosporidium and Giardia in surface water. Water Resorces 35: 4307-4316.

Mishra A, Benham BL, Mostaghimi S. 2008. Bacterial transport from agricultural lands fertilized with animal manure. Water, Air, and Soil Pollution 189: 127-134.

Neitsch SL, Arnold JG, Kiniry JR, Williams JR. 2005. Soil and water assessment tool theoretical documentation. Version 2005. GSWRLARS, BRC-TAES, Temple, Texas.

Nikolova M, Nedkov S, Nikolov V, Zuzdrov I, Genev M, Kotsev T, Vatseva R, Krumova Y. 2009. Implementation of the "KINEROS" model for estimation of the flood prone territories in the Malki Iskar river basin. Information and Security. An International Journal 24: 76-88

Oliver DM, Heathwaite AL, Fish RD, Chadwick DR, Hodgson CJ, Winter M, Butler AJ. 2009. Scale appropriate modelling of diffuse microbial pollution from agriculture. Progress in Physical Geography 33: 358-377.

Pachepsky YA, Sadeghi AM, Bradford SA, Shelton DR, Guber AK, Dao TH. 2006. Transport and fate of manure-borne pathogens: modeling perspective. Agricultural Water Management 86: 81-92. 
Parlange J-Y, Lisle I, Braddock RD, Smith RE. 1982. The threeparameter infiltration equation. Soil Science 133: 337-341.

Patni NK, Toxopeus HR, Jui PY. 1985. Bacterial quality of runoff from manured and non-manured cropland. Transactions of the ASAE 28(6): $1871-1878$.

Paul S, Haan PK, Matlock MD, Mukhtar S, Pillai SD. 2004. Analysis of the HSPF water quality parameter uncertainty in predicting peak instream fecal coliform concentrations. Transactions of the ASAE 47(1): 69-78.

Penn CJ, Bryant RB, Needelman B, Kleinman P. 2007. Spatial distribution of soil phosphorus across selected New York dairy farm pastures and hay fields. Soil Science 172: 797-810.

Renard B, Kavetski D, Kuczera G, Thyer M, Franks SW. 2010. Understanding predictive uncertainty in hydrologic modeling: The challenge of identifying input and structural errors. Water Resources Research 46: W05521, DOI:10·1029/2009WR008328.

Sadeghi AM, Arnold JG. 2002. A SWAT/microbial sub-model for predicting pathogen loading in surface and groundwater at watershed and basin scales. In Total Maximum Daily Load (TMDL) Environmental Regulations: Proceedings of ASAE, Publication number 701P0102: 56-63.

Semmens DJ, Goodrich DC, Unkrich CL, Smith RE, Woolhiser DA, Miller SN. 2008. KINEROS2 and the AGWA modeling framework. Chapter 5: In Hydrological Modelling in Arid and Semi-Arid Areas Wheater H, Sorooshian S, Sharma KD (eds). Cambridge University Press: London; pp. 49-69.

Shirmohammadi A, Chaubey I, Harmel RD, Bosh DD Muñoz-Carpena R, Dharmasri C, Sexton A, Arabi M, Wolfe ML, Frankenberger J, Graff C, Sohrabi TM. 2006. Uncertainty in TMDL models. Transactions of the ASAE 49: 1033-1049.

Soupir ML, Mostaghimi S, Yagow ER, Hagedorn C, Vaughan DH. 2006. Transport of fecal bacteria from poultry litter and cattle manures applied to pastureland. Water, Air, and Soil Pollution 169: 125-136.
Springer E P, Gifford GF, Windham MP, Thelin R, Kress M. 1983. Fecal coliform release studies and development of a preliminary nonpoint source transport model for indicator bacteria. Utah Water Research Laboratory, Utah State University, Logan, UT.

Tate KW, Atwill ER, George MR, McDougald NK, Larsen RE. 2000. Cryptosporidium parvum transport from cattle fecal deposits on California rangelands. Journal of Range Management 53: 295-299.

Tetra Tech, Inc., US Environmental Protection Agency (USEPA). 2002. The Loading Simulation Program in C $++($ LSPC) Watershed Modeling System-Users' Manual. Pasadena, CA, USA.

Thurston-Enriquez JA, Gilley JE, Eghball B. 2005. Microbial quality of runoff following land application of cattle manure and swine slurry. Journal of Water and Health 3.2: 157-171.

Tian YQ, Gong P, Radke JD, Scarborough J. 2002. Spatial and temporal modeling of microbial contaminants on grazing farmlands. Journal of Environmental Quality 31(3): 860-869.

Walker SE, Mostaghimi S, Dillaha TA. 1990. Modeling animal waste management practices: Impacts on bacteria levels in runoff from agricultural lands. Transactions of the ASAE 33: 807-817.

Wang Y, Edwards DR, Daniel TC, Scott HD. 1996. Simulation of runoff transport of animal manure constituents. Transactions of the ASAE 39(4): $1367-1378$

Woolhiser DA, Smith RE, Goodrich DC. 1990. KINEROS, A kinematic runoff and erosion model: Documentation and user manual. ARS-77. USDA, ARS, Washington, DC.

Yatheendradas S, Wagener T, Gupta H, Unkrich CL, Goodrich DC, Schaffner M, Stewart A. 2008. Understanding uncertainty in distributed flash flood forecasting for semiarid regions. Water Resources Research 44: W05S19.1-W05S19.17. 